\title{
Straightforward Method for the Preparation of Lysine-Based Double-Chained Anionic Surfactants
}

\author{
Paula Gomes, Maria João Araújo, Eduardo F. Marques, \\ Soraia Falcão, and Rodrigo O. Brito \\ CIQUP, Department of Chemistry, Faculty of Sciences, University of Porto, \\ Porto, Portugal
}

\begin{abstract}
Double-chained surfactants with potential biocompatibility have been prepared in high yields by lysine acylation with four natural saturated fatty acids $\left(\mathrm{C}_{6}\right.$ to $\left.\mathrm{C}_{12}\right)$ and with cis-undec-5-enoic acid. The surfactants were found to assemble into nanotubules in aqueous medium and, when mixed with a commercial cationic surfactant, to spontaneously form liposomes.
\end{abstract}

Keywords: Carbodiimide; Coupling; Fatty acid; Liposome; Lysine; Peptide; Surfactant

\section{INTRODUCTION}

Fatty-acid acylation is a widespread posttranslational modification of natural peptides and proteins aimed at different functional and structural biological purposes. ${ }^{[1-3]}$ Thus, the increase of protein's lipophilicity conferred by fatty-acid acylation can, among other effects, (i) increase the protein's stability against proteolytic degradation, (ii) target the protein

Received in the U.K., August 22, 2007.

Address correspondence to Paula Gomes, Centro de Investigação em Química da Universidade do Porto, Departamento de Química da Faculdade de Ciências do Porto, R. Campo Alegre 687, P-4169-007, Porto, Portugal. E-mail: pgomes@ fc.up.pt 
for certain intracellular compartments, and (iii) promote the protein's interaction and association with phospholipid bilayers in cell membranes. ${ }^{[1-6]}$ This latter feature of lipoproteins has been the driving force for $N$-fatty-acid acylation of antimicrobial peptide's $N$-terminal and/or lysine residues as a strategy to improve their antibiotic activity. ${ }^{[7-16]}$ However, the potential interest of $N$-acylation of proteinogenic amino acids with natural fatty acids to produce surface-active agents of gemini type has been little explored, despite the urgent need for new double-chain surfactants that are simultaneously efficient detergents with anti bacterial properties, biodegradable, and biocompatible. ${ }^{[17]}$ A few authors have been devoted to amino acid-based surfactants since the 1980 s, and their work has been a valuable contribution to the unveiling of the enormous potential of amino acid- and peptide-based surfactants. Some pioneer works are, for instance, those from Hidaka et al., who reported the interesting self-assembling properties of chiral $N$-(2-hydroxydodecyl) amino acids, ${ }^{[18]}$ and from Imae et al., who have studied $N$-acyl derivatives of L-aspartic acid, L-glutamic acid, and $\beta$-Alanine using capric, lauric, miristic, palmitic, or stearic acid as the acyl component. ${ }^{[19]}$ In the latter case, the authors have found interesting solution properties and morphologies for their amino acid amphiphiles, from gels to cylindrical or helical fibers and even vesicles, which opened new perspectives for biomedical applications of biocompatible surfactants. Over the past decade, Infante and coworkers have been devoted to the synthesis of amino acidbased single-chain, double-chain, and gemini surfactants through employment of several chemical and chemoenzymatic methodologies and characterized their self-aggregation, biodegradability, and toxicity properties. ${ }^{[20-30]}$ Among the different types of lipoamino acids created and studied by these authors, those derived from basic amino acids such as arginine presented interesting properties because of their low toxicity, high biodegradability, and antimicrobial activity. ${ }^{[26]}$ The same research group has also explored some lysine-derived surfactants, including $N^{\alpha}, N^{\varepsilon}$-dioctanoyl-lysine, which performed significantly better than classical anionic surfactants in terms of ocular and skin irritancy, haemolytic activity, antimicrobial properties, and aquatic toxicity. ${ }^{[31-36]}$

The wide potentialities of lysine-based double-chain anionic amphiphiles as bio- and ecofriendly surfactants with prospective industrial interest prompted us to explore alternative methods for their preparation. Synthetic methodologies were developed to give high yields at a multigram scale and involve inexpensive, safe, simple, and high-yield experimental procedures, as these are key factors for a feasible industrial development of novel surfactants. 


\section{MATERIALS AND METHODS}

L-lysine methyl ester di-hydrochloride and $N$-[(1H-benzotriazole-1-yl $)$ (dimethylamino)methylene]- $N$-methylmethanaminium $N$-oxide tetrafluoroborate (TBTU) were from Bachem (Switzerland). The solvents were of pro analisi (p.a.) quality from Merck (Germany). Fatty acids and other chemicals were all from Sigma-Aldrich (Germany). The reaction progress was monitored by thin-layer chromatography (TLC) on aluminium plates covered by a 2.5 -mm-thick layer of silica gel $60 \mathrm{~F}_{254}$ (Merck).

Fatty acid coupling to L-lysine methyl ester was achieved by standard peptide chemistry methods, using TBTU as coupling agent to yield the desired di-acylation products 1a-e (Scheme 1i) that were easily isolated by acid-base liquid extraction. Compounds 1a-e were then submitted to saponification at room temperature with an aqueous methanolic solution of sodium hydroxide, from which the target anionic amphiphiles

2<smiles>CCC(=O)O</smiles><smiles>COC(=O)[C@H](N)CCCCN</smiles>
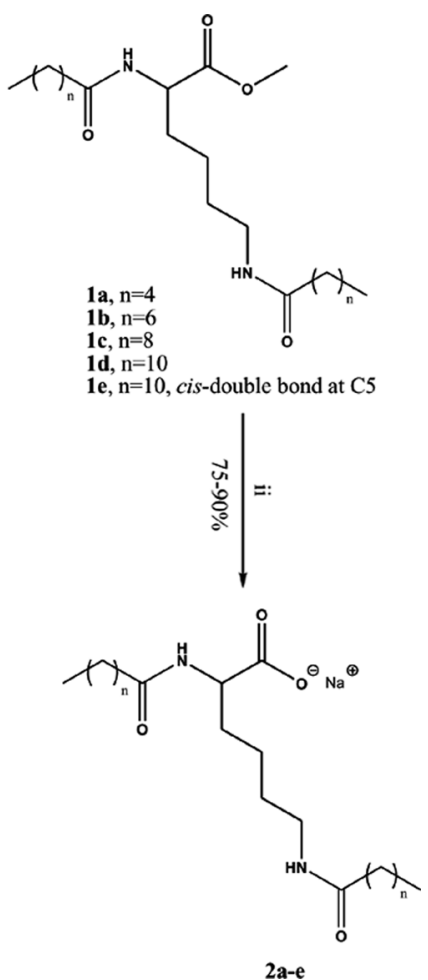

Scheme 1. Synthetic path to anionic amphiphiles 2a-e: (i) TBTU/DIEA, dichloromethane/toluene, $0{ }^{\circ} \mathrm{C} \rightarrow \mathrm{rt}$; (ii) $\mathrm{NaOH}$ in methanol-water, $0{ }^{\circ} \mathrm{C}$. 
2a-e (Scheme 1ii) were easily isolated. The structure and purity of all compounds were checked by ${ }^{1} \mathrm{H}$ NMR, ${ }^{13} \mathrm{C}$ NMR, and ESI-MS.

\section{Compounds 1a-e}

Lysine methyl ester hydrochloride $(5.0 \mathrm{mmol})$ was added to a solution of the fatty acid $(10.0 \mathrm{mmol})$ in dichloromethane $(20 \mathrm{~mL})$ and the mixture was stirred in an ice-water bath. After addition of $N$-ethyl$N, N^{\prime}$-diisopropylamine (DIEA, $\left.20.0 \mathrm{mmol}\right)$ and TBTU $(10.0 \mathrm{mmol})$, the mixture was kept at $0{ }^{\circ} \mathrm{C}$ for $2 \mathrm{~h}$. The reaction was allowed to proceed at room temperature for $72 \mathrm{~h}$, after which the solvent was evaporated and the oily residue dissolved in toluene $(40 \mathrm{~mL})$. This solution was washed three times with an aqueous solution of $5 \% \mathrm{HCl}(20 \mathrm{~mL}$ of $10 \% \mathrm{HCl}+20 \mathrm{~mL}$ of boiling water) and as many times with an aqueous solution of $15 \% \quad \mathrm{Na}_{2} \mathrm{CO}_{3}\left(20 \mathrm{~mL}\right.$ of $30 \% \mathrm{Na}_{2} \mathrm{CO}_{3}+20 \mathrm{~mL}$ of boiling water). The organic layer was then washed with boiling water $(2 \times 15 \mathrm{~mL})$, dried over anhydrous $\mathrm{Na}_{2} \mathrm{SO}_{4}$, and evaporated to dryness. The products were isolated as white solids and presented correct spectral data, as exemplified for $\mathbf{1 d}$.

\section{$N, N^{\prime}$-Di-dodecanoyl-lysine Methyl Ester (1d)}

$\eta=82 \% ; \mathrm{mp}=84-85^{\circ} \mathrm{C} . \delta_{\mathrm{H}}\left(\mathrm{CDCl}_{3}, 300 \mathrm{MHz}\right): 6.21(\mathrm{~d}, 1 \mathrm{H}, J=7.8 \mathrm{~Hz}$, $\mathrm{CO}-\mathrm{N} H-\mathrm{CH}$ ); 5.73 (br s, $\left.1 \mathrm{H}, \mathrm{CH}_{2}-\mathrm{N} H-\mathrm{CO}\right) ; 4.56(\mathrm{dt}, 1 \mathrm{H}, J=8.1$ and $\left.7.8 \mathrm{~Hz}, \mathrm{NH}-\mathrm{CH}-\mathrm{COOCH}_{3}\right), 3.72\left(\mathrm{~s}, 3 \mathrm{H}, \mathrm{CH}_{3}-\mathrm{O}\right) ; 3.22\left(\mathrm{~m}, 2 \mathrm{H}, \mathrm{CH}_{2}-\right.$ $\mathrm{NH}) ; 2.22\left(\mathrm{t}, 2 \mathrm{H}, J=7.7 \mathrm{~Hz}, \mathrm{CH}_{2}-\mathrm{CO}-\mathrm{NH}\right) ; 2.14(\mathrm{t}, 2 \mathrm{H}, J=7.7 \mathrm{~Hz}$, $\left.\mathrm{NH}-\mathrm{CO}-\mathrm{CH}_{2}\right) ; 1.68\left(\mathrm{~m}, 8 \mathrm{H}, \mathrm{CH}-\mathrm{CH}_{2}, \mathrm{CH}_{2}-\mathrm{CH}_{2}-\mathrm{NH}\right.$ and $\mathrm{CO}-\mathrm{CH}_{2}-$ $\left.\mathrm{CH}_{2}\right) ; 1.24\left(\mathrm{~m}, 34 \mathrm{H}, \mathrm{CH}_{2}-\left(\mathrm{CH}_{2}\right)_{8}-\mathrm{CH}_{3}\right.$ and $\left.\mathrm{CH}_{2}-\left(\mathrm{CH}_{2}\right)_{2}-\mathrm{NH}\right) ; 0.864$ $\left(\mathrm{t}, 6 \mathrm{H}, J=6.8 \mathrm{~Hz}, \mathrm{CH}_{2} \mathrm{CH}_{3}\right.$ ).

$\delta_{\mathrm{C}}\left(\mathrm{CDCl}_{3}, 75 \mathrm{MHz}\right): 173.5$ and $173.3(\mathrm{CO}-\mathrm{NH}) ; 173.1\left(\mathrm{COOCH}_{3}\right)$; $52.35(\mathrm{CH}) ; 51.60\left(\mathrm{CH}_{3}-\mathrm{O}\right) ; 38.69\left(\mathrm{CH}_{2}-\mathrm{NH}\right) ; 36.81$ and $36.53\left(\mathrm{CH}_{2}-\mathrm{CO}\right)$; $32.01,31.89,29.61,29.50,29.34,29.32,29.27,28.82,25.82,25.62,22.66$, and $22.28\left(\mathrm{CH}_{2}\right) ; 14.09\left(\mathrm{CH}_{3}\right)$.

Calculated for $\mathrm{C}_{31} \mathrm{H}_{61} \mathrm{~N}_{2} \mathrm{O}_{4}\left(\mathrm{MH}^{+}\right)$525.83, found 525.42.

\section{Compounds 2a-e}

To a stirred solution of $\mathbf{1 a}-\mathbf{e}(6 \mathrm{mmol})$ in methanol $(12 \mathrm{~mL})$, the equivalent volume of $1 \mathrm{M}$ aqueous $\mathrm{NaHO}(6 \mathrm{mmol})$ was added, and the reaction allowed to proceed for $3 \mathrm{~h}$ at $0{ }^{\circ} \mathrm{C}$. In the case of compounds $2 \mathrm{c}$ and $\mathbf{2 d}$, a white solid extensively precipitated and was collected by suction 
filtration, after which was rinsed with ice-cold water. In the remaining three cases, no extensive precipitation was observed, and the reaction mixtures were freeze-dried to yield the desired products as white solids that presented correct spectral data, as exemplified for $\mathbf{2 d}$.

\section{Sodium $N, N^{\prime}$-Di-dodecanoyl Lysinate (2d)}

$\eta=87 \% ; \mathrm{mp}=205-206^{\circ} \mathrm{C} . \delta_{\mathrm{H}}\left(\mathrm{CD}_{3} \mathrm{OD}, 300 \mathrm{MHz}\right): 4.23(\mathrm{~m}, 1 \mathrm{H}, \mathrm{NH}-$ $\left.\mathrm{C} H-\mathrm{COO}^{-} \mathrm{Na}^{+}\right) ; 3.14\left(\mathrm{t}, 2 \mathrm{H}, J=6.8 \mathrm{~Hz}, \mathrm{CH}_{2}-\mathrm{NH}\right) ; 2.22(\mathrm{t}, 2 \mathrm{H}$, $\left.J=7.5 \mathrm{~Hz}, \mathrm{CH}_{2}-\mathrm{CO}\right) ; 2.15\left(\mathrm{t}, 2 \mathrm{H}, J=7.6 \mathrm{~Hz}, \mathrm{CH}_{2}-\mathrm{CO}\right) ; 1.83(\mathrm{~m}, 2 \mathrm{H}, \mathrm{CH}-$ $\left.\mathrm{CH}_{2}\right) ; 1.58\left(\mathrm{~m}, 6 \mathrm{H}, \mathrm{CH}_{2}-\mathrm{CH}_{2}-\mathrm{CH}_{2}-\mathrm{NH}\right.$ and $\left.\mathrm{CO}-\mathrm{CH}_{2}-\mathrm{CH}_{2}\right) ; 1.28(\mathrm{~m}, 34 \mathrm{H}$, $\mathrm{CH}_{2}-\mathrm{CH}_{2}-\mathrm{CH}_{2}-\mathrm{NH}$ and $\left.\left(\mathrm{CH}_{2}\right)_{8}-\mathrm{CH}_{3}\right) ; 0.886\left(\mathrm{t}, 6 \mathrm{H}, J=6.5 \mathrm{~Hz}, \mathrm{CH}_{2} \mathrm{CH}_{3}\right)$. $\delta_{\mathrm{C}}\left(\mathrm{CD}_{3} \mathrm{OD}, 75 \mathrm{MHz}\right): 179.4\left(\mathrm{COO}^{-}\right) ; 176.2$ and $175.4(\mathrm{CO}-\mathrm{NH})$; $56.07(\mathrm{CH}) ; 40.29\left(\mathrm{CH}_{2}-\mathrm{NH}-\mathrm{CO}\right) ; 37.44$ and $37.25\left(\mathrm{CH}_{2}-\mathrm{CO}\right) ; 33.73$ $\left(\mathrm{CH}_{2}-\mathrm{CH}\right) ; 33.12\left(\mathrm{CH}_{2}-\mathrm{CH}_{2}-\mathrm{CH}_{3}\right) ; 30.82,30.80,30.73,30.69,30.57$, 30.47, 30.42, 30.16, 27.17, 27.09, 24.28 and $23.78\left(\mathrm{CH}_{2}\right) ; 14.51\left(\mathrm{CH}_{3}\right)$.

Calculated for $\mathrm{C}_{30} \mathrm{H}_{57} \mathrm{~N}_{2} \mathrm{O}_{4} \mathrm{Na}\left(\mathrm{MNa}^{+}\right)$555.76; found 555.44.

\section{RESULTS AND DISCUSSION}

\section{Establishment of the Synthetic Method for Compounds 1a-e}

The first synthetic approach to prepare lysine $N^{\alpha}, N^{\varepsilon}$-diacyl derivatives 1a-e was based on the employment of $N, N^{\prime}$-dicyclohexylcarbodiimide (DCCI) as coupling agent, as this is an inexpensive, mild, and safe acylation method. ${ }^{[37]}$ The acylation reaction was tested using lauric (dodecanoic) acid as the acyl component, and a product was formed and isolated by column chromatography on silica. ${ }^{1} \mathrm{H}$ NMR and electrospray ionization mass spectrometry (ESI-MS) spectra of the product identified it as $N, N^{\prime}$-dicyclohexyl- $N$-dodecylurea instead of the target compound (Scheme 2). $N$-Acylurea formation can become a serious problem in DCCI-mediated coupling when the attack of the nucleophile (lysine amino groups in our case) to the reactive $O$-acylisourea intermediate is sluggish. This favors the ON acyl migration that leads to the stable (i.e., unreactive) $\mathrm{N}$-acylurea, decreasing or even zeroing the probability of obtaining the desired condensation product. ${ }^{[38]}$

\section{Attempts to Prepare 1d by DCCI-Mediated Coupling}

Lysine methyl ester hydrochloride $(5.0 \mathrm{mmol})$ was added to a solution of the fatty acid $(10.0 \mathrm{mmol})$ in dichloromethane $(20 \mathrm{~mL})$, and the mixture was stirred in an ice-water bath. After addition of DCCI $(11.0 \mathrm{mmol})$, 


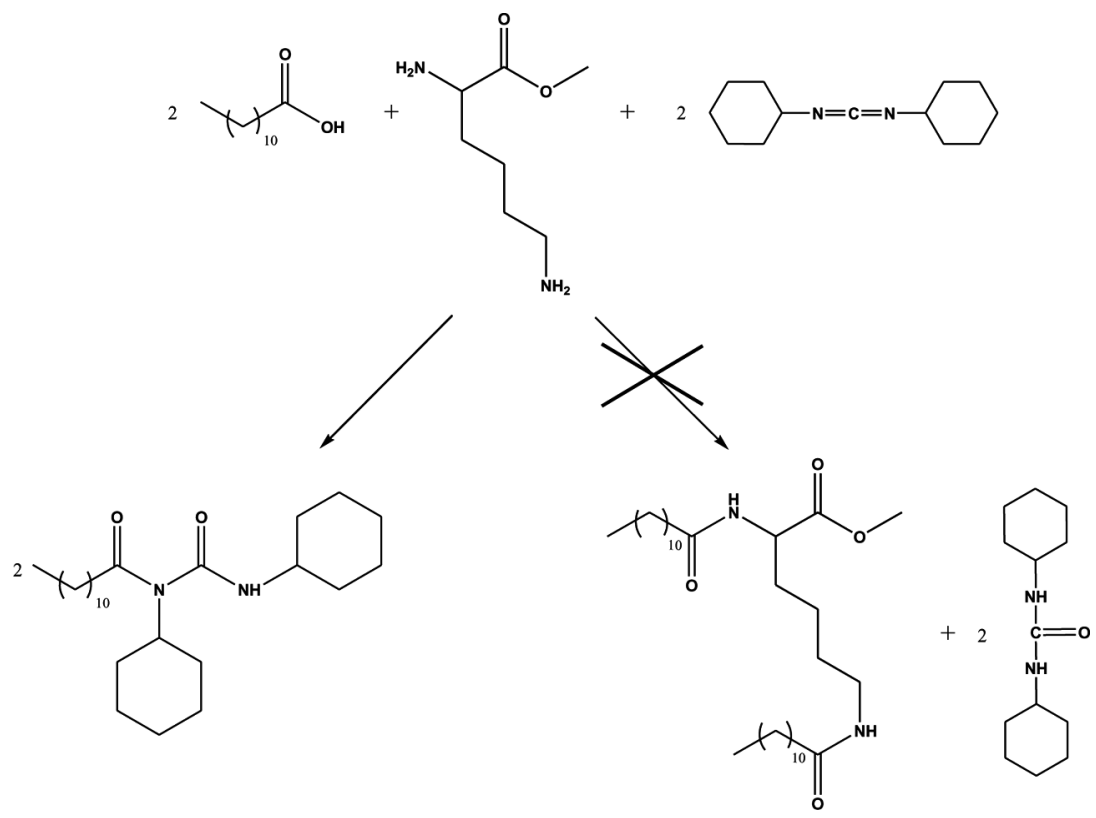

Scheme 2. Formation of $N, N^{\prime}$-dicyclohexyl- $N$-dodecanoylurea in the place of the desired condensation product when DCCI was used as coupling reagent.

the mixture was kept at $0{ }^{\circ} \mathrm{C}$ for $2 \mathrm{~h}$. The reaction was allowed to proceed at room temperature for $24 \mathrm{~h}$, after which a second portion of DCCI $(5 \mathrm{mmol})$ was added. After $48 \mathrm{~h}$, the solid fraction was removed by suction filtration and identified (TLC) as unreacted DCCI. The filtrate was evaporated to dryness and observed (TLC) to be composed by one major product and unreacted starting materials. This mixture was separated by column chromatography on silica using dichloromethane/ acetone 10:1 (v/v) as eluant. The pure white waxy product was isolated and identified by ${ }^{1} \mathrm{H}$ NMR and ESI-MS.

\section{$N, N^{\prime}$-Dicyclohexyl- $N$-dodecanoylurea}

$\eta=32 \% . \delta_{\mathrm{H}}\left(\mathrm{CDCl}_{3}, 300 \mathrm{MHz}\right): 7.16(\mathrm{~s}, 1 \mathrm{H}, \mathrm{CO}-\mathrm{NH}-\mathrm{CH}) ; 3.79(\mathrm{~m}, 2 \mathrm{H}$, cyclohexyl $\mathrm{CH}) ; 2.40\left(\mathrm{t}, 2 \mathrm{H}, \mathrm{COCH}_{2}\right), 1.26(\mathrm{~m}, 38 \mathrm{H}$, dodecanoyl and cyclohexyl $\left.\mathrm{CH}_{2}\right) ; 0.88\left(\mathrm{t}, 3 \mathrm{H}, \mathrm{CH}_{3}\right)$.

Calculated for $\mathrm{C}_{25} \mathrm{H}_{46} \mathrm{~N}_{2} \mathrm{O}_{2}\left(\mathrm{MH}^{+}\right)$407.36; found 407.43.

We then used TBTU, ${ }^{[39]}$ a more efficient, yet more expensive, coupling agent than DCCI. TBTU-mediated coupling not only led to the 
exclusive formation of target compounds 1a-e (Scheme 1i) in high yields but also enabled product isolation with high purity through acid-base extractions that are faster, easier, and cheaper than chromatographic techniques. Thus, unreacted starting materials and both the tetramethylurea and 1-hydroxybenzotriazole (HOBt) by-products were completely removed by washing the organic layer with $5 \%$ aqueous $\mathrm{HCl}$ followed by $15 \%$ aqueous $\mathrm{Na}_{2} \mathrm{CO}_{3}$, so that products $1 \mathrm{a}-\mathbf{e}$ were easily isolated in high yield and purity by simply evaporating to dryness the resulting organic layer. In the course of the extractions, compounds 1a-e displayed surface-active properties that were easily dealt with. Therefore, toluene was used as the organic solvent, as others such as dichloromethane, ethyl acetate, hexane, or ethyl ether promoted the formation of intractable emulsions or the preferred localization of the compounds at the liquidliquid interface. Further, use of boiling aqueous solutions in the extractions was seen to avoid emulsification. These simple procedures led to excellent results up to a 5-gram synthesis of $\mathbf{1 a - e . ~}$

Infante and coworkers have previously synthesised similar $N^{\alpha}, N^{\varepsilon}$ diacyl-lysine derivatives by addition of lysine sodium salt to the corresponding acyl chloride, followed by product precipitation with hydrochloric acid and a final recrystallization step to yield the final product with adequate purity. ${ }^{[32]}$ This is indeed an efficient method, but our findings clearly show that TBTU-mediated synthesis of 1a-e is advantageous from all points of view, as it involves safer starting materials and milder reaction conditions and avoids recrystallizations.

As compared to cheaper coupling agents, even if carbodiimide-based coupling could be made to work (for instance, by addition of HOBt as auxiliary nucleophile), ${ }^{[40]}$ it would most certainly require chromatographic purification steps to fully eliminate the remains of unreacted carbodiimide and its urea by-product. It could be argued that this problem would be solved by employment of the water-soluble carbodiimide (WSC) $N$-ethyl- $N^{\prime}$-(3-dimethylaminopropyl)carbodiimide ${ }^{[41]}$ that, together with its urea, can be removed by liquid-liquid extraction. However, the price of WSC is ca. four times higher than that of TBTU, which makes the latter a more attractive choice.

\section{Preparation of Compounds 2a-e as Potentially Bio- and Ecofriendly Soaps}

The lysine $N^{\alpha}, N^{\varepsilon}$-diacyl derivatives 1a-e were saponified with sodium hydroxide in aqueous-methanolic medium (Scheme 1ii). The saponifications were carried out at $0{ }^{\circ} \mathrm{C}$ with no excess alkali to avoid amino acid racemisation ${ }^{[42]}$ and reached completion within $3 \mathrm{~h}$. The 
higher-molecular-weight saturated products $\mathbf{2 c}$ and $\mathbf{2 d}$ readily precipitated from the reaction mixture and were simply isolated by suction filtration followed by extensive rinsing of the solid with ice-cold water. As compounds $\mathbf{2 a}, \mathbf{2 b}$, and $\mathbf{2 e}$ did not precipitate under the conditions employed, their reaction mixtures were freeze dried to give the pure products. Once more, experimental procedures to obtain the target anionic amphiphiles 2a-e from their ester precursors 1a-e were fast, clean, inexpensive, and straightforward, leading to excellent results.

\section{Self-assembly Properties of Lysine-Based Surfactants}

Preliminary studies on the aqueous self-assembly of the newly synthesized anionic surfactants have revealed some very interesting features. The shortest chain $\mathbf{2 a}$ and the unsaturated $\mathbf{2 e}$ amphiphiles are soluble at room temperature, whereas $\mathbf{2 b}-\mathbf{d}$ are insoluble. The surfactants alone in water do not form micellar solutions nor liposome dispersions, as is the case with conventional single- and double-chained compounds. Instead, they have a tendency to self-aggregate into large tubular structures or fibers, for which electrostatic interactions and hydrogen bonding play a key structural role. ${ }^{[43]}$ In Fig. 1, one can observe the type of micron-sized, flexible tubules formed by the unsaturated amphiphile, in a $0.5 \mathrm{wt} \%$ dispersion in water, as observed under a light microscope with differential interference contrast. Another technically very relevant property displayed by these amphiphiles is exemplified by compound $\mathbf{2 d}$ and can be seen in Fig. 2. Upon mixing with a conventional cationic single-chained surfactant such as dodecyltrimethyl ammonium bromide, spontaneouly formed liposomes with high long-term stability can be obtained. ${ }^{[43]}$ Such observations open up a possible application of these amphiphiles in the design of efficient encapsulation-based drug delivery systems.

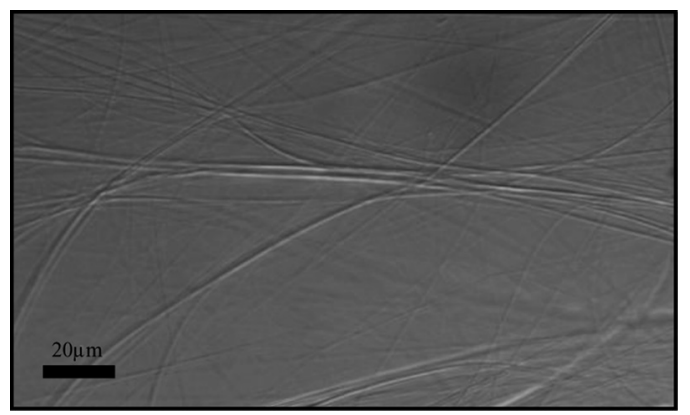

Figure 1. Light micrograph for a $0.5 \mathrm{wt} \%$ aqueous dispersion of compound $2 \mathrm{e}$, displaying self-assembled long tubular aggregates $\left(400 \times, \theta=25^{\circ} \mathrm{C}\right)$. 


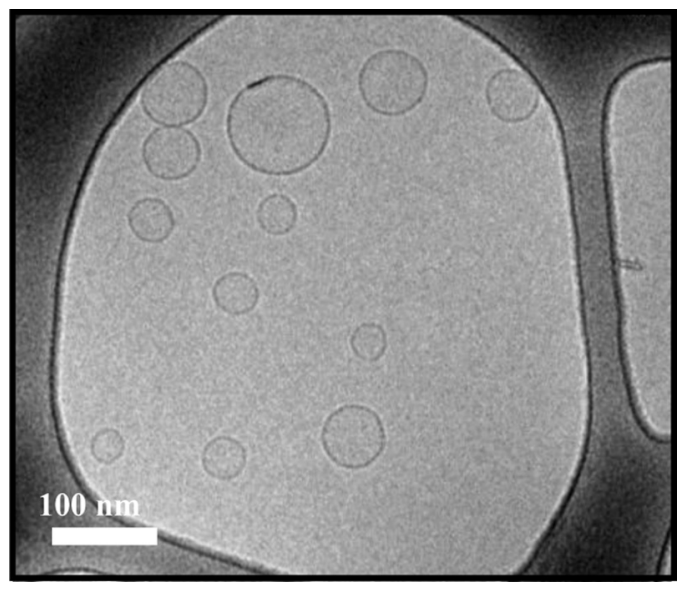

Figure 2. Cryotransmission electron micrograph of a $0.5 \mathrm{wt} \%$ aqueous dispersion of compound 2d with the cationic surfactant DTAB (molar ratio 1:3), where selfassembled unilamellar liposomes can be seen $\left(\theta=25^{\circ} \mathrm{C}\right)$.

\section{CONCLUSION}

Ten lysine-based double-chained anionic surfactants have been prepared by a clean and straightforward two-step synthesis. The synthetic procedures were successfully carried out at up to a 5-g scale, leading to excellent yields and involving only simple and inexpensive compound isolation techniques, such as liquid-liquid extraction, freeze drying, or product precipitation.

Physicochemical studies carried out on some of the anionic amphiphiles produced have shown that the neat compounds self-assemble in water into tubular aggregates but can also form stable unilamellar liposomes in binary mixtures. These properties are good indicators for the potential pharmaceutical interest of these compounds.

In conclusion, the double-chain anionic amphiphiles herein described, based on a proteinogenic amino acid and natural fatty acids, are promising candidates for the industrial development of novel surfactants with prospective biocompatibility, biodegradability, and versatility.

\section{ACKNOWLEDGMENTS}

The authors thank Fundação para a Ciência e Tecnologia (FCT, LisbonPortugal) for financial support through project POCTI/QUI/ 44296/2002 and through pluriannual funding to research unit Centro 
de Investigação em Química da Universidade do Porto (CIQUP, PortoPortugal). Thanks are due to Cláudia Correia for laboratory assistance.

\section{REFERENCES}

1. Dunphy, J. T.; Linder, M. E. Signalling functions of protein palmitoylation. Biochim. Biophys. Acta 1998, 1436, 245.

2. Johansson, J. Structure and properties of surfactant protein C. Biochim. Biophys. Acta 1998, 1408, 161.

3. Resh, M. D. Fatty acylation of proteins: New insights into membrane targeting of myristoylated and palmitoylated proteins. Biochim. Biophys. Acta 1999, $1451,1$.

4. Arnould, S.; Takahashi, M.; Camadro, J. M. Acylation stabilizes a proteaseresistant conformation of protoporphyrinogen oxidase, the molecular target of diphenyl ether-type herbicides. Proc. Natl. Acad. Sci. USA 1999, 96, 14825 .

5. McCabe, J. B.; Berthiaume, L. G. Functional roles for fatty acylated aminoterminal domains in subcellular localization. Mol. Biol. Cell 1999, 10, 3771.

6. Raaijmakers, J. M.; de Bruijn, I.; de Kock, M. J. D. Cyclic lipopeptide production by plant-associated pseudomonas spp.: Diversity, activity, biosynthesis and regulation. Mol. Plant-Micr. Interact. 2006, 19, 699.

7. Chicharro, C.; Granata, C.; Lozano, R.; Andreu, D.; Rivas, L. N-Terminal fatty acid substitution increases the leishmanicidal activity of CA(1-7)M(29), a cecropin-melittin hybrid peptide. Antimicrob. Agents Chemother. 2001, 45, 2441.

8. Toniolo, C.; Crisma, M.; Formaggio, F.; Peggion, C.; Epand, R. F.; Epand, R. M. Lipopeptaibols, a novel family of membrane active, antimicrobial peptides. Cell. Mol. Life Sci. 2001, 58, 1179.

9. Mak, P.; Pohl, J.; Dubin, A.; Reed, M. S.; Bowers, S. E.; Fallon, M. T.; Shafer, W. M. The increased bactericidal activity of a fatty acid-modified synthetic antimicrobial peptide of human cathepsin $G$ correlates with its enhanced capacity to interact with model membranes. Int. J. Antimicrob. Agents 2003, 21, 13.

10. Avrahami, D.; Shai, Y. Bestowing antifungal and antibacterial activities by lipophilic acid conjugation to D,L-amino acid-containing antimicrobial peptides: A plausible mode of action. Biochemistry 2003, 42, 14946.

11. Lockwood, N. A.; Haseman, J. R.; Tirrell, M. V.; Mayo, K. H. Acylation of SC4 dodecapeptide increases bactericidal potency against gram-positive bacteria, including drug-resistant strains. Biochem. J. 2004, 378, 93.

12. Oh, H. S.; Kim, S. H.; Cho, H. J.; Lee, K. H. Development of novel lipidpeptide hybrid compounds with antibacterial activity from natural cationic antibacterial peptides. Bioorg. Med. Chem. Lett. 2004, 14, 1109.

13. Chu-Kung, A. F.; Bozzelli, K. N.; Lockwood, N. A.; Haseman, J. R.; Mayo, K. H.; Tirrell, M. V. Promotion of peptide antimicrobial activity by fatty acid conjugation. Bioconj. Chem. 2004, 15, 530. 
14. Malina, A.; Shai, Y. Conjugation of fatty acids with different lengths modulates the antibacterial and antifungal activity of a cationic biologically inactive peptide. Biochem. J. 2005, 390, 695.

15. Straus, S. K.; Hancock, R. E. W. Mode of action of the new antibiotic for gram-positive pathogens daptomycin: Comparison with cationic antimicrobial peptides and lipopeptides. Biochim. Biophys. Acta-Biomembranes 2006, $1758,1215$.

16. Porat, Y.; Marynka, K.; Tam, A.; Steinberg, D.; Mor, A. Acyl-substituted dermaseptin S4 derivatives with improved bactericidal properties, including on oral microflora. Antimicrob. Agents Chemother. 2006, 50, 4153.

17. Nnanna, I. A.; Xia, J. Protein-Based Surfactants: Synthesis, Physicochemical Properties and Applications; Marcel Dekker: New York, 2001.

18. Hidaka, H.; Murata, M.; Onai, T. Helical aggregates of chiral N-(2-hydroxydodecyl) amino acids. J. Chem. Soc., Chem. Comm. 1984, 562.

19. Imae, T.; Takahashi, Y.; Muramatsu, H. Formation of fibrous molecular assemblies by amino acid surfactants in water. J. Am. Chem. Soc. 1992, $114,3414$.

20. Infante, M. R.; Molinero, J.; Erra, P. Lipopeptidic surfactants, II: Acidic and basic $\mathrm{N} \alpha$-lauroyl-L-arginine dipeptides from pure amino acids. J. Am. Oil Chem. Soc. 1992, 69, 647.

21. Piera, E.; Comelles, F.; Erra, P.; Infante, M. R. New alquil amide type cationic surfactants from arginine. J. Chem. Soc., Perkin Trans. 2 1998, 335.

22. Infante, M. R.; Seguer, J.; Pinazo, A.; Vinardell, M. P. Synthesis and properties of asymmetrical nonionic double chain surfactants from lysine. J. Disp. Sci. Technol. 1999, 20, 621.

23. Pinazo, A.; Wen, X. Y.; Pérez, L.; Infante, M. R.; Franses, E. I. Aggregation behavior in water of monomeric and gemini cationic surfactants derived from arginine. Langmuir 1999, 15, 3134.

24. Pegiadou, S.; Pérez, L.; Infante, M. R. Synthesis, characterization and surface properties of 1-N-1-tryptophan-glycerol-ether surfactants. J. Surfact. Deterg. 2000, 3, 517.

25. Pinazo, A.; Pérez, L.; Infante, M. R.; Pons, R. Unconventional vesicle-toribbon transition behaviour of diacyl glycerol amino acid based surfactants in extremely diluted systems induced by $\mathrm{pH}$-concentration effects. Phys. Chem. Chem. Phys. 2004, 6, 1475.

26. Infante, M. R.; Pérez, L.; Pinazo, A.; Clapés, P.; Morán, M. C.; Angelet, M.; García, M. T.; Vinardell, M. P. Amino acid-based surfactants. Comptes Rendus Chimie 2004, 7, 583.

27. Benavides, T.; Martínez, V.; Mitjans, M.; Infante, M. R.; Morán, M. C.; Clapés, P.; Clothier, R.; Vinardell, M. P. Assessment of the potential irritation and photoirritation of novel amino acid-based surfactants by in vitro methods as alternative to the animal tests. Toxicology 2004, 201, 87.

28. Varka, E. M.; Coutoulli-Argyropoullou, E.; Infante, M. R.; Pegiadou, S. Synthesis, characterization, and surface properties of phenylalanine-glycerol ether surfactants. J. Surfact. Deterg. 2004, 7, 409. 
29. Rosa, M.; Infante, M. R.; Miguel, M. D.; Lindman, B. Spontaneous formation of vesicles and dispersed cubic and hexagonal particles in amino acid-based catanionic surfactant systems. Langmuir 2006, 22, 5588.

30. Sánchez, L.; Mitjans, M.; Infante, M. R.; Vinardell, M. P. Determination of interleukin- $1 \alpha$ in human NCTC 2544 keratinocyte cells as a predictor of skin irritation from lysine-based surfactants. Toxicol. Lett. 2006, 167, 40.

31. Vives, M. A.; Macián, M.; Seguer, J.; Infante, M. R.; Vinardell, M. P. Irritancy potential induced by surfactants derived from lysine. Toxicol. in vitro $1997,11,779$.

32. Vives, M. A.; Macián, M.; Seguer, J.; Infante, M. R.; Vinardell, M. P. Hemolytic action of anionic surfactants of the diacyl lysine type. Comp. Biochem. Physiol. C 1997, 118, 71.

33. Vives, M. A.; Infante, M. R.; García, E.; Selve, C.; Maugras, M.; Vinardell, M. P. Erythrocyte hemolysis and shape changes induced by new lysinederivate surfactants. Chem.-Biol. Interact. 1999, 118, 1.

34. Sánchez, L.; Mitjans, M.; Infante, M. R.; Vinardell, M. P. Assessment of the potential skin irritation of lysine-derivative anionic surfactants using mouse fibroblasts and human keratinocytes as an alternative to animal testing. Pharm. Res. 2004, 21, 1637.

35. Sánchez, L.; Mitjans, M.; Infante, M. R.; Vinardell, M. P. Potential irritation of lysine derivative surfactants by hemolysis and HaCaT cell viability. Toxicol. Letters 2006, 161, 53.

36. Sánchez, L.; Mitjans, M.; Infante, M. R.; García, M. T.; Manresa, M. A.; Vinardell, M. P. The biological properties of lysine-derived surfactants. Amino Acids 2007, 32, 133.

37. Sheehan, J. C.; Hess, G. P. A new method of forming peptide bonds. J. Am. Chem. Soc. 1955, 77, 1067.

38. Lloyd-Williams, P.; Albericio, F.; Giralt, E. Chemical Approaches to the Synthesis of Peptides and Proteins; CRC Press: Boca Raton, FL, 1997.

39. Knorr, R.; Trzeciak, A.; Bannwarth, W.; Gillesen, D. New coupling reagents in peptide chemistry. Tetrahedron Lett. 1989, 30, 1927.

40. Koenig, W.; Geiger, R. Racemisierung bei Peptidsynthesen. Chem. Ber. 1970, 103, 2024.

41. Sheehan, J. C.; Preston, J.; Cruickshank, P. A. A rapid synthesis of oligopeptide derivatives without isolation of intermediates. J. Am. Chem. Soc. 1965, 87, 2492.

42. Bodanszky, M.; Bodanszky, A. The Practice of Peptide Synthesis; SpringerVerlag: Berlin (Germany), 1984.

43. Brito, R. O.; Marques, E. F.; Gomes, P.; Falcão, S.; Söderman, O. Selfassembly in a catanionic mixture with an amino acid-derived surfactant: From mixed micelles to spontaneous vesicles. J. Phys. Chem. B 2006, 110, 18158. 